\title{
A Unique Subpopulation of Murine DNA Polymerase $\alpha /$ Primase Specifically Interacts with Polyomavirus T Antigen and Stimulates DNA Replication
}

\author{
K. MOSES AND C. PRIVES* \\ Department of Biological Sciences, Columbia University, New York, New York 10027
}

Received 1 September 1993/Returned for modification 4 November 1993/Accepted 30 December 1993

\begin{abstract}
Murine cells or cell extracts support the replication of plasmids containing the replication origin (ori-DNA) of polyomavirus (Py) but not that of simian virus 40 (SV40), whereas human cells or cell extracts support the replication of SV40 ori-DNA but not that of Py ori-DNA. It was shown previously that fractions containing DNA polymerase $\alpha$ /primase from permissive cells allow viral ori-DNA replication to proceed in extracts of nonpermissive cells. To extend these observations, the binding of Py $T$ antigen to both the permissive and nonpermissive DNA polymerase $\alpha$ /primase was examined. Py $T$ antigen was retained by a murine DNA polymerase $\alpha$ /primase but not by a human DNA polymerase $\alpha /$ primase affinity column. Likewise, a Py $T$ antigen affinity column retained DNA polymerase $\alpha$ /primase activity from murine cells but not from human cells. The murine fraction which bound to the Py $T$ antigen column was able to stimulate Py ori-DNA replication in the nonpermissive extract. However, the DNA polymerase a/primase activity in this murine fraction constituted only a relatively small proportion (approximately 20 to $40 \%$ ) of the total murine DNA polymerase $\alpha$ /primase that had been applied to the column. The DNA polymerase $\alpha /$ primase purified from the nonbound murine fraction, although far more replete in this activity, was incapable of supporting Py DNA replication. The two forms of murine DNA polymerase $\alpha$ /primase also differed in their interactions with Py $T$

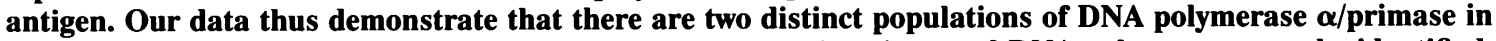
murine cells and that species-specific interactions between $T$ antigen and DNA polymerases can be identified. They may also provide the basis for initiating a novel means of characterizing unique subpopulations of DNA polymerase $\alpha$ /primase.
\end{abstract}

Both simian virus 40 (SV40) and polyomavirus (Py) display fairly stringent host species requirements. Primate cells are permissive for the replication of SV40 but not Py, whereas rodent cells are permissive for the replication of Py but not SV40 (reviewed in reference 48). In each case, the ability of a cell to produce infectious viral progeny is related to whether it has the ability to support the replication of the appropriate viral minichromosome. The existence of a factor(s) that is required for the production of viral progeny in permissive cells but not nonpermissive cells is suggested by the observation that SV40 production can be rescued after fusion of nonpermissive murine cells bearing integrated SV40 sequences with uninfected permissive monkey cells (2). One way in which a permissive factor may control the initiation of viral DNA replication is through a direct role in DNA replication.

The ability to carry out SV40 DNA replication in vitro, as first established by $\mathrm{Li}$ and Kelly (25), has proven valuable for isolating and studying the host proteins that contribute to eukaryotic DNA replication. This is because, except for a single virally encoded protein, the large $\mathrm{T}$ antigen, all other factors are host cell derived. Use of the SV40 system has made possible the functional identification of several human DNA replication factors (for reviews, see references $7,21,22$, and 45). The first event in the initiation of DNA replication is the binding of a phosphorylated subclass of $T$ antigen to a palindromic sequence in the viral origin $(4,17,39)$. A multimeric $T$ antigen-nucleoprotein complex then assembles at and melts the origin sequences $(11,28)$. The DNA helicase activity of $T$

${ }^{*}$ Corresponding author. Mailing address: Department of Biological Sciences, Columbia University, New York, NY 10027. Phone: (212) 854-2557. Fax: (212) 865-8246. antigen $(11,44)$ extends origin unwinding in concert with a cellular single-stranded-DNA-binding protein (RPA/RFA/ SSB) and topoisomerase I or II, forming a preinitiation complex $(5,11,16,23,57,58)$.

DNA polymerase $\alpha$ /primase has been shown to interact directly with $\mathrm{T}$ antigen $(12-15,18,43)$ and RPA (13). This may be the mechanism by which DNA polymerase $\alpha /$ primase is recruited to the initiation complex and by which $T$ antigen couples origin recognition and unwinding to the synthesis of DNA (55). The DNA primase, shown to be tightly associated with DNA polymerase $\alpha$, synthesizes a short RNA primer on each template strand, which is then extended by the DNA polymerase $\alpha$. These first strands synthesized at the replication origin are probably the Okazaki fragments of the lagging strand.

It has been proposed that there is a multiprotein complex switch on the leading strand (49). At the $3^{\prime}$ end of the first Okazaki fragment, the polymerase $\alpha$ is replaced. The replacing complex contains DNA polymerase $\delta$ and its accessory proteins RFC and PCNA (references 50 and 51 and references therein). DNA polymerase $\varepsilon$ and PCNA may also be involved (30; for a review, see reference 1). Morrison et al. (30) also propose that the polymerase $\delta$ multiprotein complex replaces the DNA polymerase $\alpha /$ primase on the lagging strand. While a comparable system in which Py $T$ antigen supports the replication of Py origin-containing DNA in murine cell extracts in vitro has been established (31), there has been less progress in identifying the murine cellular factors involved in Py DNA replication.

The SV40 and Py T antigens are fairly homologous in terms of amino acid sequence $(>60 \%)$ and biochemical function. Like its SV40 counterpart, Py T antigen binds specifically to 
DNA sequences containing multiple copies of the consensus pentanucleotide $5^{\prime}$-GAGGC-3' that are located both adjacent to and within the minimal origin region $(10,38,41)$. Like SV40 $\mathrm{T}$ antigen, Py T antigen also exhibits ATPase (19) and DNA helicase $(42,53)$ activities. Furthermore, analogous to SV40 T antigen, Py T antigen displays ATP-dependent origin binding (27) and hexamer formation (54). However, despite their similar functions and structure, SV40 and Py T antigens display distinctly different cell species specificity for mediating viral ori-DNA replication in vitro. Only extracts of primate cells replicate SV40 ori-DNA in the presence of SV40 T antigen $(26,32)$. Conversely, Py $\mathrm{T}$ antigen requires Py ori-DNA and murine extracts (31). Murakami et al. (32) showed that immunologically or chromatographically purified DNA polymerase $\alpha /$ primase is capable of conferring species specificity for DNA replication in nonpermissive extracts. Thus, human DNA polymerase $\alpha$ /primase allowed SV40 T antigen-mediated SV40 ori-DNA replication in murine cell extracts (32). Reciprocally, Py ori-DNA synthesis required murine DNA polymerase $\alpha /$ primase for DNA replication in human cell extracts (31). Permissiveness is therefore unlikely to be determined by the presence of negative regulators. Rather, it is likely that either DNA polymerase $\alpha /$ primase or a copurifying entity (or both) is actually the permissive factor(s). Here, by using affinity columns containing either DNA polymerase $\alpha$ /primase or Py T antigen, we present evidence that supports this suggestion. Furthermore, our data indicate that a unique fraction of the species-specific population of DNA polymerase is capable of stimulating viral ori-DNA replication when supported by the nonpermissive-cell extract.

\section{MATERIALS AND METHODS}

Materials. Deoxynucleoside triphosphates (dNTPs) labeled with ${ }^{32} \mathrm{P}$ and $\left[{ }^{3} \mathrm{H}\right] \mathrm{TTP}$ were obtained from New England Nuclear; most other reagents were purchased from Sigma Corp. Peroxidase-conjugated anti-mouse or -rat immunoglobulin $\mathrm{G}$ (IgG) was purchased from Organon Teknika Corp. Protein $\mathrm{G}$ and A Sepharose were purchased from Pharmacia. Phosphocellulose (P11) was obtained from the Whatman Laboratory Division. Py $\mathrm{T}$ antigen-specific monoclonal antibody-producing hybridomas PAb 820 (3) and F4 and F5 (37) were gifts from J. Bolen and D. Pallas, respectively. DNA polymerase $\alpha$-specific hybridomas SJK 132-20, 287-38, and 237-71 (47) against DNA polymerase $\alpha /$ primase were purchased from the American Type Culture Collection. The purified monoclonal antibody SJK $132-20$ was kindly provided by and used at the suggestion of the E. Fanning group.

Preparation of cell extracts. Hypotonic extracts were prepared by the method described by Li and Kelly (25). Human HeLa cells (16 liters at $5 \times 10^{5}$ cells per ml) and murine FM3A cells $\left(16\right.$ liters at $5 \times 10^{5}$ cells per $\left.\mathrm{ml}\right)$ were harvested and disrupted in hypotonic buffer ( $20 \mathrm{mM}$ HEPES [ $N$-2-hydroxyethylpiperazine- $N^{\prime}$-2-ethanesulfonic acid, $\mathrm{pH} 7.5$ ], $5 \mathrm{mM}$ potassium chloride, $1.5 \mathrm{mM} \mathrm{MgCl}, 1 \mathrm{mM}$ dithiothreitol [DTT]) by Dounce homogenization. Cell debris and nuclei were then removed by centrifugation of the suspension at $20,000 \mathrm{rpm}$ for $30 \mathrm{~min}$, and the supernatant was collected and either used directly or stored at $-70^{\circ} \mathrm{C}$.

Immunoaffinity purification of DNA polymerase $\alpha /$ primase. DNA polymerase $\alpha /$ primase was purified from both human and murine hypotonic extracts prepared from 16 liters $(5 \times$ $10^{5}$ cells per ml) by a modification of the method described by Nasheuer and Grosse (33). The hypotonic extract was adjusted to $\mathrm{pH} 6.8$ to 7.0 , and approximately $10 \mathrm{ml}$ of equilibrated phosphocellulose was added per $30 \mathrm{mg}$ of hypotonic extract.
The slurry was then rocked for $12 \mathrm{~h}$. The phosphocellulose was packed into a column and washed with equivalent column volumes of 70,130, and $190 \mathrm{mM}$ potassium phosphate (tribasic salt), pH 6.8 to 7.0. A DNA polymerase activity was eluted with 2 column volumes of $250 \mathrm{mM}$ potassium phosphate, at a rate of $10 \mathrm{ml} / \mathrm{h}$. Undialyzed fractions were screened for DNA polymerase activity; active fractions were pooled and dialyzed against hypotonic buffer. To $5 \mathrm{ml}$ of the dialyzed fraction was added approximately $1 \mathrm{ml}$ of a $50 \%$ solution of SJK 287-38 coupled to protein G-Sepharose and rocked for $12 \mathrm{~h}$. Bound proteins were eluted from packed columns with buffer containing $20 \mathrm{mM}$ Tris- $\mathrm{HCl}$ (pH 8.5), 1 mM EDTA, $10 \%$ glycerol, 1 $\mathrm{mM}$ DTT, $0.5 \mathrm{M} \mathrm{NaCl}$, and $50 \%$ ethylene glycol.

SV40 T antigen and Py T antigen were purified from Sf 27 insect cells that had been infected with the appropriate recombinant baculovirus, vEV55SVT (36) or vEV55PYT (40), expressing SV40 T antigen and Py T antigen, respectively, by the immunopurification procedures described by Wang et al. (52).

$P y$ antigen and DNA polymerase $\alpha /$ primase affinity columns. Py $\mathrm{T}$ antigen affinity columns were constructed by passing clarified supernatant extracted from Sf27 insect cells that had been infected with recombinant baculovirus (vEV55PyT) over PAb 820 coupled to protein G-Sepharose.

DNA polymerase $\alpha /$ primase affinity columns were prepared by passing hypotonic murine or human cell extracts over a column containing anti-DNA polymerase $\alpha$ antibody SJK 132-20 coupled to protein G-Sepharose. The column was judged to be saturated when no increase in units of DNA polymerase $\alpha$ activity eluting from the column was observed when an increasing number of units were added to the column.

In vitro DNA replication. Reaction mixtures for both SV40 and Py ori-DNA replication contained, in a total volume of 50 $\mu l$, Py ori-DNA (pBE102) or SV40 ori-DNA (pSVS) at the quantities indicated below and in the figure legends; $40 \mathrm{mM}$ creatine phosphate ( $\mathrm{pH} 7.7$; di-Tris salt); $100 \mu \mathrm{g}$ of creatine kinase per ml; $7 \mathrm{mM} \mathrm{MgCl}_{2} ; 0.5 \mathrm{mM}$ DTT; $4 \mathrm{mM} \mathrm{ATP;} 200$ $\mu \mathrm{M}$ each CTP, UTP, and GTP; $100 \mu \mathrm{M}$ each dATP, dGTP, and dCTP; $20 \mu \mathrm{M}\left[\alpha-{ }^{32} \mathrm{P}\right] \mathrm{dTTP}(3,000 \mathrm{Ci} / \mathrm{mmol})$; and hypotonic extracts, cellular fractions, and $\mathrm{T}$ antigen as indicated. pBE102 is the A2 strain of Py, nucleotides 5022 to 1562 , inserted into a pml vector (24), and pSVS contains the entire SV40 genome inserted at the Bam HI site of pBR322. The incubations were carried out at 33 and $37^{\circ} \mathrm{C}$ for Py and SV40 replication, respectively. The reactions were terminated by chilling the reaction mixes at $4^{\circ} \mathrm{C}$.

DNA synthesis products were detected by analysis of either semiconservative DNA replication products (DpnI-resistant DNA products) or acid-precipitatable radiolabel. Product analysis was done as follows. The DNA replication reaction was terminated by the addition of sodium dodecyl sulfate (SDS) and EDTA to a final concentration of $0.2 \%$ and $15 \mathrm{mM}$, respectively. Proteinase $\mathrm{K}(0.2 \mathrm{mg} / \mathrm{ml})$ digestion was then conducted for $1 \mathrm{~h}$ at $37^{\circ} \mathrm{C}$. The DNA was then phenolchloroform extracted once and ethanol precipitated, and the DNA was resuspended. The samples were then subjected to $0.8 \%$ agarose gel electrophoresis for $1.5 \mathrm{~h}$ at $150 \mathrm{~V}$, followed by autoradiography.

DNA polymerase and primase assays. The DNA polymerase and primase assays were performed as described by Suzuki et al. (46). DNA polymerase reaction mixtures (total volume, 30 $\mu \mathrm{l})$ contained $20 \mathrm{mM}$ Tris- $\mathrm{HCl}(\mathrm{pH} 8), 3.3 \mathrm{mM}$ 2-mercaptoethanol, $5 \mathrm{mM} \mathrm{MgCl}, 0.2 \mathrm{mg}$ of bovine serum albumin (BSA) per ml, $100 \mu \mathrm{M}$ dATP, $100 \mu \mathrm{M}$ dCTP, $100 \mu \mathrm{M}$ dGTP, $20 \mu \mathrm{M}$ TTP, and $20 \mu \mathrm{M}\left[{ }^{3} \mathrm{H}\right] \mathrm{dTTP}(0.1 \mathrm{Ci} / \mathrm{mmol})$. The template was nicked salmon sperm DNA $(500 \mu \mathrm{g} / \mathrm{ml})$. The reaction mix was incubated for $1.5 \mathrm{~h}$ at $37^{\circ} \mathrm{C}$. 

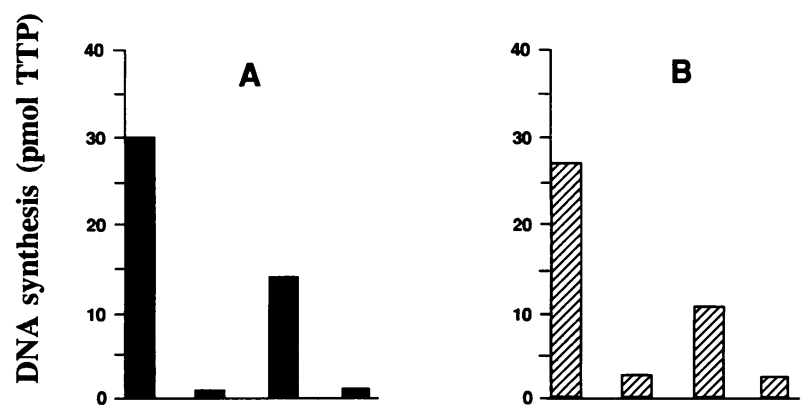

$\begin{array}{lllll}\text { DNA ori } & \text { SV } & \text { SV } & \text { SV } & \text { SV } \\ \text { T antigen } & \text { SV } & \text { SV } & \text { SV } & \text { SV } \\ \text { S100 } & \text { h } & \text { m } & \text { m } & \text { m } \\ + \text { pol /pri } & -- & - & \text { h } & \text { m }\end{array}$

$\begin{array}{llll}\text { Py } & \text { Py } & \text { Py } & \text { Py } \\ \text { Py } & \text { Py } & \text { Py } & \text { Py } \\ \text { m } & \text { h } & \text { h } & \text { h } \\ - & -- & \text { m } & \text { h }\end{array}$

FIG. 1. Immunopurified DNA polymerase $\alpha /$ primase stimulates DNA replication in human and murine hypotonic extracts. (A) SV40 DNA replication in human $(h)$ and murine $(m)$ hypotonic cell extract. Reaction mixtures $(50 \mu \mathrm{l})$ contained SV40 ori-DNA (300 ng), SV40 T antigen (600 $\mathrm{ng})$, human (h) or murine (m) extract (26 $\mu \mathrm{g})$, and human or murine immunoaffinity-purified DNA polymerase $\alpha$ activity ( + pol/ pri) $(4 \mathrm{U})$. After incubation for $3 \mathrm{~h}$ at $33^{\circ} \mathrm{C}$, DNA replication was measured by incorporation of radiolabeled nucleotides into acidprecipitable counts. (B) Py DNA replication in human or murine extract. Reaction mixtures contained Py $\mathrm{T}$ antigen $(1.5 \mu \mathrm{g})$, Py ori-DNA (100 ng), human or murine extract, and DNA polymerase $\alpha /$ primase, as indicated.

The DNA primase assay was a Klenow (1 unit per reaction mix)-coupled reaction with poly $(\mathrm{dT})$ as a template. The reaction mixture (total volume, $30 \mu \mathrm{l}$ ) contained $50 \mathrm{mM}$ Tris- $\mathrm{HCl}$ (pH 7.8), $9 \mathrm{mM} \mathrm{MgCl} 2,4 \mathrm{mM}$ DTT, $200 \mu \mathrm{g}$ of BSA per ml, 5 $\mathrm{mM}$ ATP, and $100 \mu \mathrm{M}\left[{ }^{3} \mathrm{H}\right] \mathrm{dATP}(0.1 \mathrm{Ci} / \mathrm{mmol})$. The reaction mix was incubated for $30 \mathrm{~min}$ at $30^{\circ} \mathrm{C}$. Cellular fractions were added as indicated in the figure legends. The reactions were terminated by chilling at $4^{\circ} \mathrm{C}$, and reaction products were determined after acid precipitation and scintillation counting.

Immunoblotting. Protein fractions were subjected to SDSpolyacrylamide gel electrophoresis (PAGE) and then electrophoretically transferred to a nitrocellulose filter. The filter was blocked with $1 \%$ milk in phosphate-buffered saline (PBS) and incubated with antibody supernatant. After exposure to the first antibody, the filters were blocked again before being incubated with a second-antibody detection system (peroxidase-conjugated anti-mouse or -rat IgG). The nitrocellulose was then exposed to the color reagent 4-chloro-1-naphthol (12 $\mathrm{mg}$ ), with $4 \mathrm{ml}$ of ethanol, $20 \mathrm{ml}$ of PBS, and $20 \mu \mathrm{l}$ of $30 \%$ hydrogen peroxide.

\section{RESULTS}

Reconstitution of DNA replication by the addition of DNA polymerase $\boldsymbol{\alpha} /$ primase. To initiate these experiments, we first extended the observations of Murakami et al. (31). Human and murine DNA polymerase $\alpha$ /primases were purified by immunoaffinity procedures from extracts of human Hela and murine FM3A cells, respectively. The replication of SV40 ori-DNA was supported by human but not by murine hypotonic extract. However, addition of immunopurified human DNA polymerase $\alpha$ /primase complex stimulated SV40 ori-DNA replication in the murine hypotonic extract (Fig. 1A). Conversely, Py ori-DNA replication required immunopurified murine DNA polymerase $\alpha /$ primase complex for replication in human hypotonic extract (Fig. 1B). This demonstrates that both the human and murine DNA polymerase $\alpha /$ primase complexes contain dominant permissive factors.

Murine DNA polymerase $\alpha$ columns preferentially bind Py $T$ antigen. An interaction between human DNA polymerase $\alpha /$ primase and SV40 T antigen was previously identified by reversibly coupling $\mathrm{T}$ antigen to a monoclonal antibody column and demonstrating that a human fraction containing DNA polymerase $\alpha /$ primase activity was retained by this column (43). We used a related approach (diagrammed in Fig. 2A) to determine whether a DNA polymerase $\alpha /$ primase column might similarly retain Py $\mathrm{T}$ antigen. From the results shown in Fig. 1, it was predicted that differences in the relative avidity of DNA polymerases from permissive and nonpermissive cells for Py $T$ antigen might be detected.

Extracts of insect cells containing Py $\mathrm{T}$ antigen were passed over columns of either murine or human DNA polymerase $\alpha /$ primase (Fig. 2B). A peak of Py $\mathrm{T}$ antigen was detected eluting from the murine DNA polymerase $\alpha$ column at 340 to $370 \mathrm{mM}$ potassium phosphate in fractions 7 and 8 (Fig. 2B, panel 1). By contrast, a human DNA polymerase $\alpha /$ primase column retained extremely low levels of Py $\mathrm{T}$ antigen (Fig. 2B, panel 2). Similarly, the SJK 132-20 column lacking DNA polymerase $\alpha$ /primase did not retain Py T antigen (Fig. 2B, panel 3). We conclude from these experiments that Py $T$ antigen preferentially binds a host-specific DNA polymerase $\alpha /$ primase activity.

Py $T$ antigen columns discriminate between murine and human DNA polymerase $\alpha /$ primase. To confirm that Py $\mathrm{T}$ antigen preferentially interacts with DNA polymerase $\alpha /$ primase from murine cells, the converse experiment was conducted. Py $\mathrm{T}$ antigen affinity columns were prepared, and their ability to retain DNA polymerase $\alpha$ /primase from murine and human hypotonic extracts was investigated. Figure $3 \mathrm{~A}$ shows the elution of murine DNA polymerase activity from a Py T antigen column. DNA polymerase activity was eluted from a Py $\mathrm{T}$ antigen column loaded with murine hypotonic extract over a broad range of potassium phosphate concentrations, with a peak at $350 \mathrm{mM}$. In parallel, when a Py $\mathrm{T}$ antigen affinity column was loaded with equivalent units of human hypotonic extract, little or no DNA polymerase activity was retained. The human hypotonic extract was able to support SV40 ori-DNA replication, and in a reciprocal experiment, the human DNA polymerase $\alpha$ /primase activity bound to an SV40 T antigen affinity column (data not shown). As a control, an equivalent protein quantity of insect hypotonic extract (infected with an unrelated baculovirus) was passed over a column of PAb 820 coupled to protein G-Sepharose before it was loaded with equivalent units of murine hypotonic extract. Again, a much reduced elution of DNA polymerase activity was detected, and what little there was eluted at approximately $100 \mathrm{mM}$ potassium phosphate. Thus, the data show that Py $\mathrm{T}$ antigen affinity columns preferentially bind a DNA polymerase activity from murine cells.

The murine fractions that eluted off the Py T antigen column were also tested for their ability to stimulate Py ori-DNA replication in nonpermissive human hypotonic extracts (Fig. 3B). The peak murine DNA polymerase $\alpha$ activity fraction (fraction 12 in the experiment shown in Fig. $3 \mathrm{~A}$ and $5 \mathrm{~A}$ ) resulted in the greatest stimulation of DNA replication activity. Figure 4A shows the dose response of Py ori-DNA replication to the peak murine fraction (fraction 12). In the absence of Py $T$ antigen, no stimulation of DNA replication activity was detected, suggesting that the peak murine fraction does not contain significant quantities of Py $T$ antigen. Furthermore, in the absence of the human hypotonic extract, the peak murine fraction alone did not support DNA replication, 

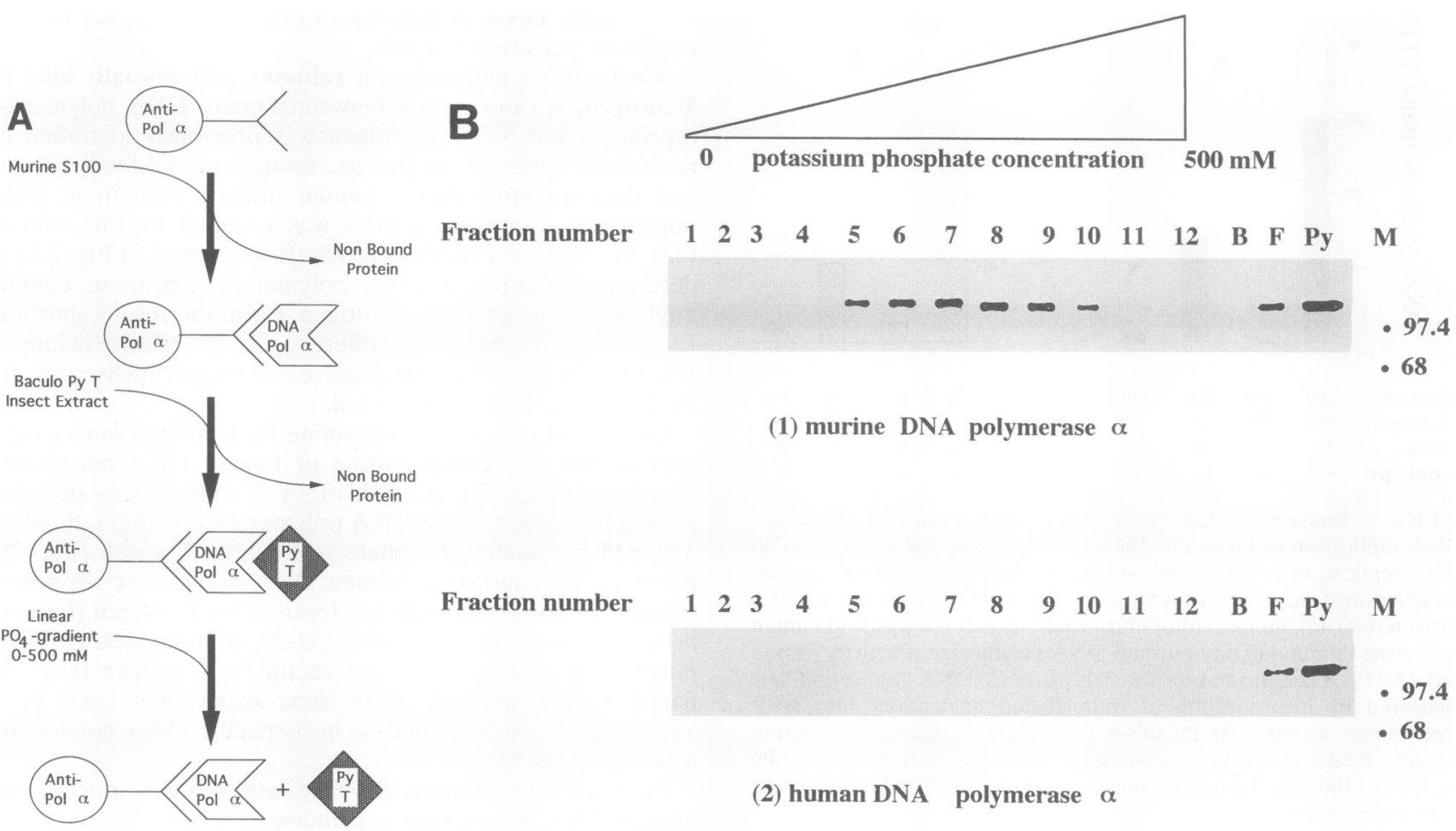

(2) human DNA polymerase $\alpha$

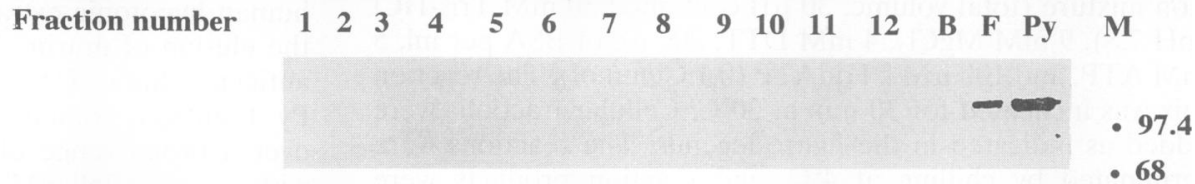

(3) no DNA polymerase $\alpha$

FIG. 2. (A) Diagram of protocol for Py $\mathrm{T}$ antigen binding to and elution from DNA polymerase $\alpha /$ primase affinity columns. The DNA polymerase $\alpha /$ primase affinity columns were prepared by passing human hypotonic extract $(730 \mathrm{mg}, 2.2 \mathrm{U}$ of DNA polymerase $\alpha /$ primase per $\mathrm{mg})$ or equivalent units of murine hypotonic extract $(890 \mathrm{mg}, 1.8 \mathrm{U}$ of DNA polymerase $\alpha /$ primase per $\mathrm{mg})$ over a 5 -ml column containing DNA polymerase $\alpha$ monoclonal antibody SJK 132-20 coupled to protein G-Sepharose. All columns were equilibrated with hypotonic buffer. Before loading with clarified supernatant extracted from Sf27 insect cells infected with the recombinant baculovirus vEV55PyT, the bound proteins were eluted with a $60-\mathrm{ml}$ linear potassium phosphate $(\mathrm{pH} 7.5)$ gradient $(0$ to $1 \mathrm{M})$. Collected fractions $(5 \mathrm{ml})$ were numbered 1 through 13 . (B) Py T antigen in DNA polymerase $\alpha$ /primase affinity column eluates. Each $5-\mathrm{ml}$ fraction was acid precipitated and resuspended in $0.1 \mathrm{ml}$ of hypotonic buffer. A 20- $\mu$ l aliquot was analyzed by SDS-PAGE and Western blot for Py T antigen with Py-specific PAb 820 and peroxidase-conjugated second antibody. Lane B, material boiled off of $30 \mu \mathrm{l}$ of a $50 \%$ solution of the beads after elution. Lane F, 20- $\mu$ l aliquot of the crude insect extract that did not bind to the column. Lane Py, purified Py T antigen marker. The positions of size markers are shown (in kilodaltons).

showing that the Py T antigen affinity column had not retained a complex of proteins capable of supporting replication. The DNA polymerase activity of the peak fraction was definitively identified by using the specific DNA polymerase $\alpha$ inhibitor monoclonal antibody SJK 132-20 (6). In the presence of SJK 132-20, DNA polymerase activity was markedly inhibited, while in the presence of the nonimmune mouse IgG, insignificant inhibition of DNA polymerase activity was observed (Fig. 4B). From this result, we conclude that at least $90 \%$ of the DNA polymerase activity bound to the Py $\mathrm{T}$ antigen affinity column was DNA polymerase $\alpha$.

Unique population of DNA polymerase $\alpha$ /primase stimulates DNA replication. The amount of DNA polymerase activity that was bound to and eluted from Py $\mathrm{T}$ antigen columns represented only a relatively minor fraction (approximately 20 to $40 \%$ ) of the total DNA polymerase $\alpha$ in the starting extract. In the experiment shown in Fig. 3, 36\% of the total DNA polymerase $\alpha$ was bound to Py T antigen. The observation that a relatively small percentage of the available DNA polymerase $\alpha$ /primase binds to $T$ antigen was reproducible even when similar amounts of extract were passed over larger Py $\mathrm{T}$ antigen columns, indicating that we were working in the range of subsaturating quantities of DNA polymerase $\alpha /$ primase (data not shown). This suggested that the nonbound DNA polymerase $\alpha /$ primase might differ in its interactions with Py $T$ antigen from DNA polymerase $\alpha /$ primase which had bound to the $T$ antigen column. To test this, we rechromatographed the nonbound fraction on a Py $\mathrm{T}$ antigen column (Fig. 

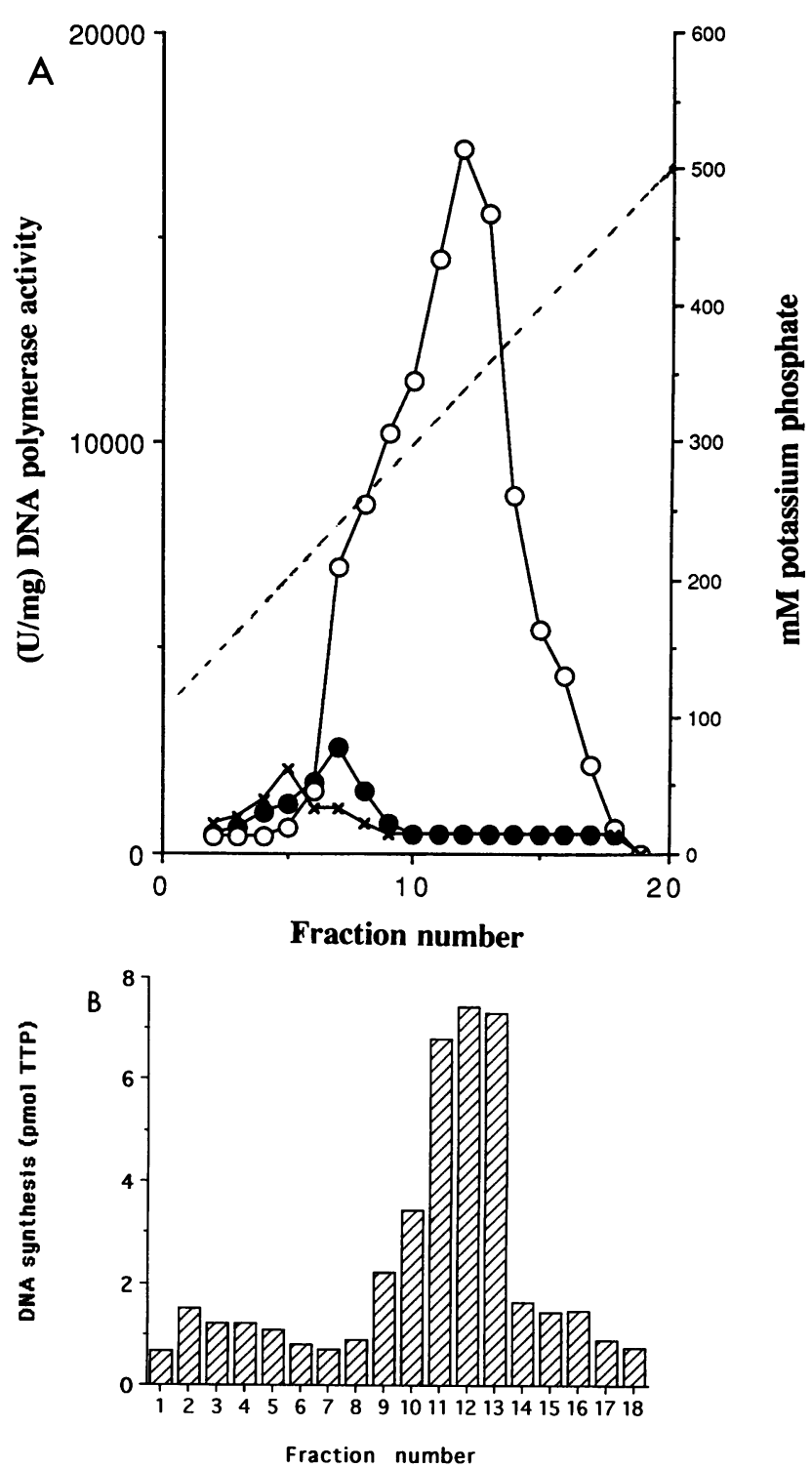

FIG. 3. (A) DNA polymerase activity of fractions eluted from the Py $T$ antigen affinity columns. Py $T$ antigen columns were prepared by passing crude extracts of recombinant-baculovirus vEV55PyT-infected insect cells over a column of Py-specific antibody PAb 820 coupled to protein G-Sepharose. Approximately $5 \mathrm{mg}$ of Py $\mathrm{T}$ antigen bound to each $\mathrm{ml}$ of the anti-Py $\mathrm{T}$ antigen column. Murine extract $(1.01 \mathrm{~g}$ of protein, 1.6 $\mathrm{U}$ of DNA polymerase $\alpha /$ primase per $\mathrm{mg}$, prepared from batches of 16 liters containing a total of $8 \times 10^{9}$ cells) was passed over the Py $\mathrm{T}$ antigen columns. Bound proteins were eluted with a linear potassium phosphate gradient ( 0 to $1.0 \mathrm{M})$, and eluted fractions were tested for DNA polymerase activity (O). An identical Py T antigen affinity column that was loaded with equivalent units of human extract ( $0.63 \mathrm{~g}$ of protein, $2.2 \mathrm{U}$ of DNA polymerase $\alpha /$ primase per $\mathrm{mg}$ ) was treated with the same protocol (O); an extract of insect cells infected with an unrelated baculovirus was passed over an anti-Py $T$ antigen column before it was loaded with equivalent units of murine extract $(X)$. The potassium phosphate gradient is shown by the dashed line. (B) Stimulation of Py ori-DNA replication in human hypotonic extract by fractions eluting from a Py $T$ antigen affinity column. Fractions $(14 \mu \mathrm{l})$ from the Py $\mathrm{T}$ antigen affinity column shown in panel A were added to Py ori-DNA replication reaction mixes containing human extract and Py $\mathrm{T}$ antigen as shown in Fig. 1. After incubation for $3 \mathrm{~h}$ at $33^{\circ} \mathrm{C}$, DNA replication was measured by incorporation of radiolabeled nucleotides into acid-precipitable counts.

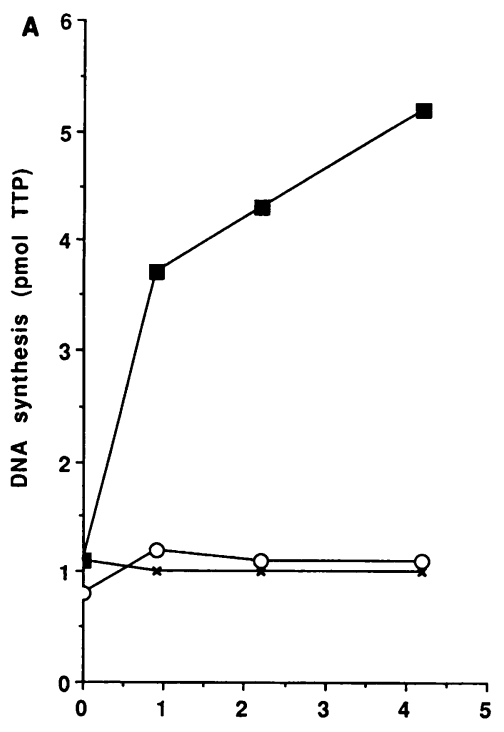

units DNA polymerase activity

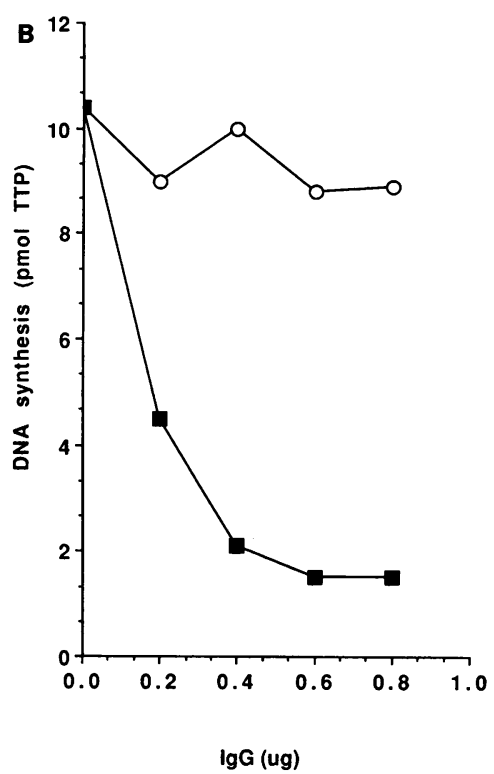

FIG. 4. (A) Stimulation of Py ori-DNA replication in human hypotonic extract by the peak DNA polymerase $\alpha$ activity fraction. The peak fraction $(15,000 \mathrm{U} / \mathrm{mg}$, fraction 12 from Fig. 3) was added to DNA replication reaction mixes in the indicated quantities and incubated for $3 \mathrm{~h}$ at $33^{\circ} \mathrm{C}$ with $(\square)$ and without $(\bigcirc)$ Py $\mathrm{T}$ antigen and in the absence of human extract but with Py $\mathrm{T}$ antigen $(X)$. (B) Identification of the DNA polymerase activity that bound to the Py $\mathrm{T}$ antigen affinity columns. A 165-ng amount of the peak fraction (number 12, 15,000 U/mg) was added to the DNA polymerase reaction mix in the presence of the indicated quantities of purified antibody SJK $132-20(\square)$ or nonimmune IgG $(\bigcirc)$.

5). In Fig. 5A, showing the total units of DNA polymerase activity eluted from the Py $\mathrm{T}$ antigen affinity column loaded with murine hypotonic extract, the peak of eluted activity occurred at $350 \mathrm{mM}$ potassium phosphate. However, in Fig. $5 \mathrm{~B}$, showing the total units of DNA polymerase activity eluted from a Py $\mathrm{T}$ antigen affinity column loaded with the nonbound 

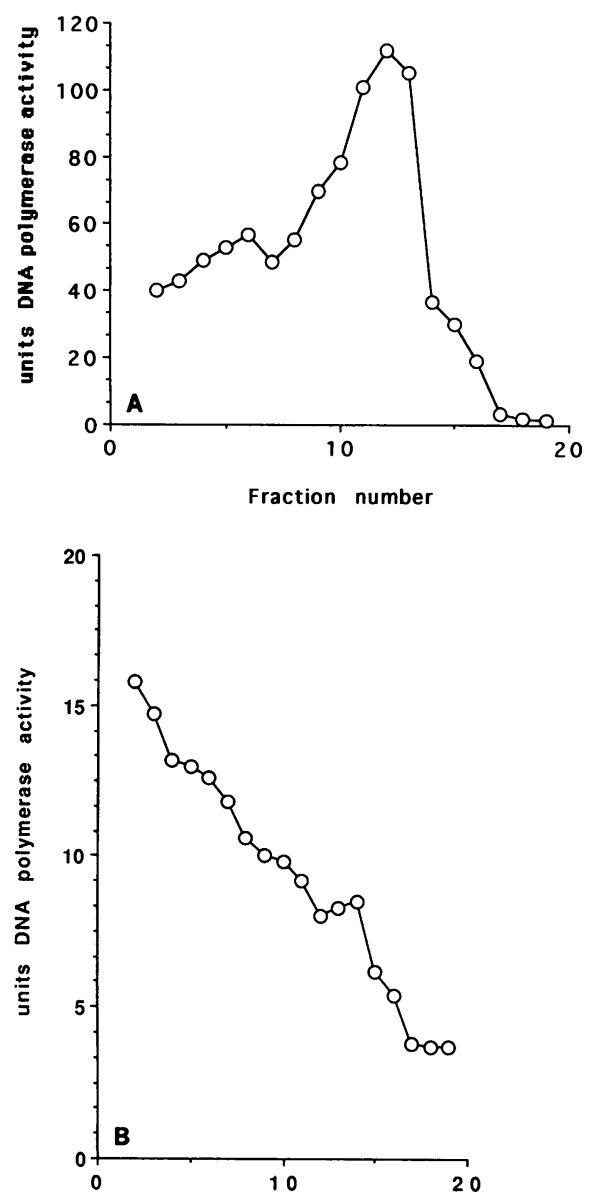

Fraction number

FIG. 5. Nonbound fraction does not contain a DNA polymerase $\alpha$ population that will specifically bind to a Py $\mathrm{T}$ affinity column. (A) Total DNA polymerase activity, expressed in units (picomoles per hour), eluted from the 5-ml Py T antigen affinity column loaded with murine extract shown in Fig. 3A. (B) One-fifth of the nonbound fraction from Fig. 3A, equivalent to $270 \mathrm{U}$, was loaded onto a previously unused $1-\mathrm{ml}$ Py $\mathrm{T}$ affinity column. Bound proteins were eluted with a linear potassium phosphate gradient (0 to $1.0 \mathrm{M})$, and eluted fractions were tested for DNA polymerase activity.

fraction, there was no comparable peak of DNA polymerase activity. Note that only one-fifth of the nonbound fraction and Py $\mathrm{T}$ antigen column were used in Fig. 5B, accounting for the reduced number of units of DNA polymerase detected. This suggests that the Py $T$ antigen column bound a uniquely different DNA polymerase activity.

We tested the ability of immunopurified murine DNA polymerase $\alpha /$ primase from murine hypotonic extract, the Py T antigen-bound fraction, and the nonbound fraction to stimulate Py ori-DNA replication supported by human hypotonic extract (Fig. 6A and B). DNA polymerase $\alpha$ /primase that was either directly immunopurified from murine hypotonic extracts or immunopurified after binding to and elution from a Py $\mathrm{T}$ antigen column was active in stimulating Py ori-DNA replication supported by human hypotonic extract over the dose range shown in Fig. 6A. However, DNA polymerase $\alpha /$ primase immunopurified from the fraction that did not bind to the Py $\mathrm{T}$ antigen column was virtually inactive in stimulating DNA replication over a comparable range of added DNA poly- merase units. Although similar units of directly immunopurified DNA polymerase and Py $T$ antigen-bound DNA polymerase $\alpha /$ primase were added, the former was clearly more active in supporting DNA replication.

Replication products were also analyzed by examining the quantities of ${ }^{32} \mathrm{P}$-labeled DNA generated in DNA replication reaction mixtures (Fig. 6B). DNA polymerase $\alpha /$ primase that was directly immunopurified from the murine hypotonic extract was more active in stimulating replication than that which was immunopurified from the Py $\mathrm{T}$ antigen-bound fraction (compare lanes 3 to 7 and 8 to 12). Whether this is because of a general loss of activity as a result of the Py $\mathrm{T}$ antigen column step or is due to the presence of additional stimulatory factors in the murine extract that copurify with DNA polymerase $\alpha /$ primase but do not adhere to the Py $\mathrm{T}$ antigen column is not known at present. DNA polymerase $\alpha$ /primase immunopurified from the fraction that did not bind to the Py $T$ antigen column was virtually inactive in stimulating DNA replication over a comparable range of added DNA polymerase units (see lanes 13 to 17). In the absence of Py $T$ antigen, the human hypotonic extract did not support Py DNA replication (lane 2), nor did addition of Py $\mathrm{T}$ antigen to the reaction mixture result in significant levels of replicated DNA (lane 1).

A possible explanation for the dissimilarities in activities of the two populations of DNA polymerases is the existence of an inhibitor in the nonbound fraction DNA polymerase $\alpha /$ primase. This was tested by mixing the stimulatory DNA polymerase $\alpha /$ primase and the nonbound DNA polymerase $\alpha /$ primase (Fig. 7). Across the dose range used, the nonbound DNA polymerase $\alpha /$ primase was found not to inhibit the stimulatory fraction.

It is well established that purified DNA polymerase $\alpha$ is tightly associated with a DNA primase (reviewed in reference 55). Another reasonable explanation for the dissimilarities in activities of the two populations of DNA polymerases is that there are differences in the extent of their DNA primase activity. Therefore, the ratios of the DNA polymerase to DNA primase activities were determined for some of the fractions tested in the previous experiment (Fig. 8). Because the results of this analysis showed that there was no significant variation in the relative activities of the two enzymes in the stimulatory and nonstimulatory DNA polymerase $\alpha$ /primase fractions, we conclude that the differences observed are not due to reduced DNA primase activity.

Two populations of murine DNA polymerase $\alpha /$ primase differ in their affinity for Py $T$ antigen. The Py $T$ antigen-bound murine DNA polymerase $\alpha /$ primase fraction was purified by its ability to interact uniquely with Py $\mathrm{T}$ antigen and was thus distinguished from the DNA polymerase $\alpha /$ primase of the murine fraction that did not bind to Py $T$ antigen. We examined the ability of immobilized DNA polymerase $\alpha /$ primase from both the Py $\mathrm{T}$ antigen-bound and nonbound murine fractions to retain Py $\mathrm{T}$ antigen by loading extracts of insect cells that had been infected with the Py $\mathrm{T}$ antigen baculovirus onto the DNA polymerase columns (Fig. 9). The SJK 132-20 columns bound similar absolute quantities of units from the Py $\mathrm{T}$ bound and nonbound fractions. The DNA polymerase $\alpha /$ primase column constructed from the Py $T$ antigen-bound fraction retained a substantial amount of Py $T$ antigen; the bound Py $\mathrm{T}$ antigen was eluted by 350 to $400 \mathrm{mM}$ potassium phosphate. By contrast, the nonbound DNA polymerase $\alpha /$ primase affinity column retained a significantly lower amount of Py $T$ antigen which was eluted with approximately $200 \mathrm{mM}$ potassium phosphate. This confirmed our observation that murine cell extracts contain at least two populations of DNA polymerase $\alpha /$ primase that differ in their affinity for Py $\mathrm{T}$ 


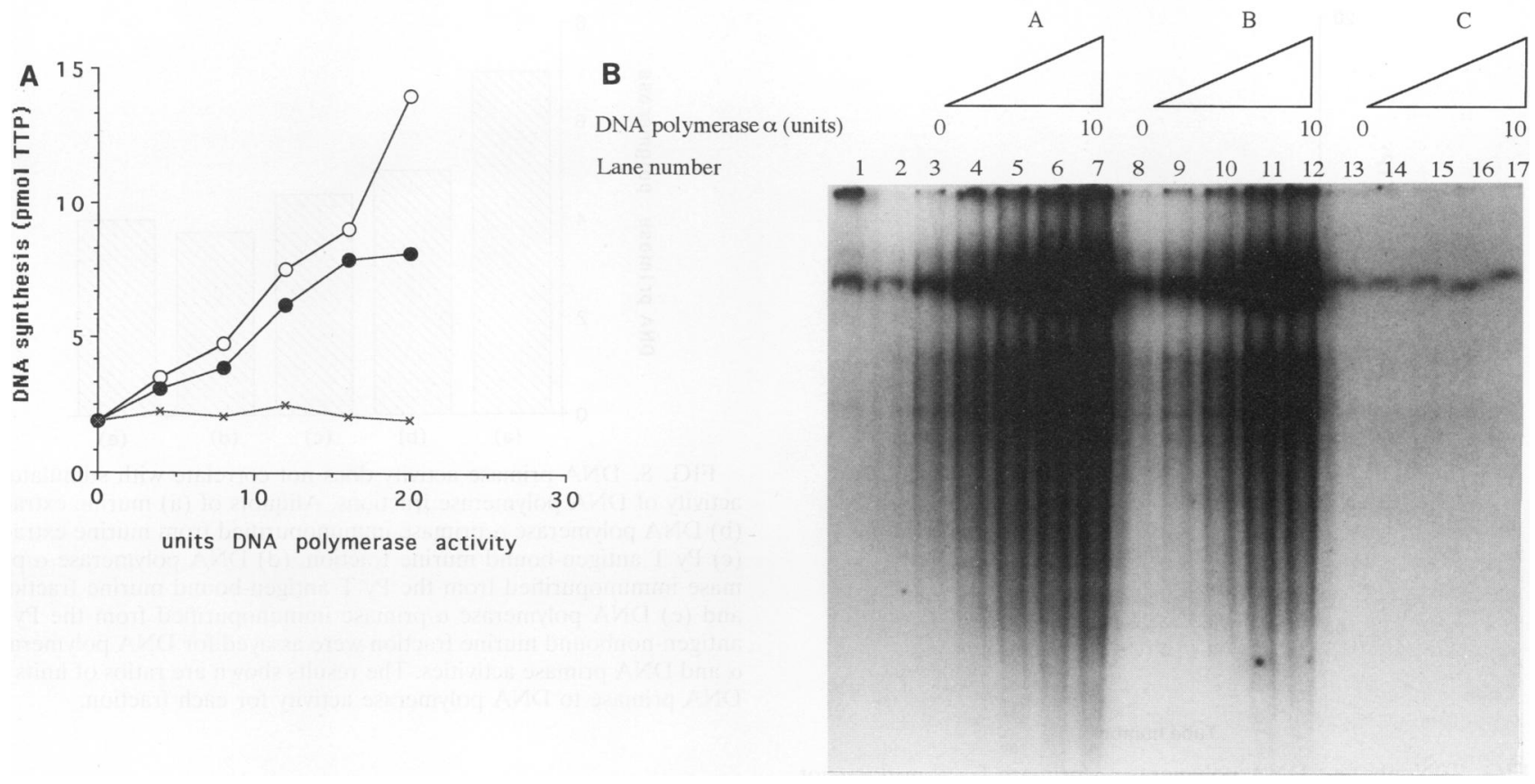

FIG. 6. Py $\mathrm{T}$ antigen columns retain a unique population of DNA polymerase $\alpha$ /primase. (A) Effect of immunopurified DNA polymerase $\alpha /$ primase on Py ori-DNA replication in the human extract. The following fractions were added to Py ori-DNA replication reaction mixtures (described in the legend to Fig. 1B) in the indicated quantities and incubated for $3 \mathrm{~h}$ at $33^{\circ} \mathrm{C}$ : DNA polymerase $\alpha(28,500 \mathrm{U} / \mathrm{mg})$ immunopurified from murine extract $(\mathrm{O})$, DNA polymerase $\alpha(19,000 \mathrm{U} / \mathrm{mg})$ immunopurified from the Py $\mathrm{T}$ antigen-bound murine fraction $(0)$, and DNA polymerase $\alpha(25,000 \mathrm{U} / \mathrm{mg})$ directly immunopurified from the Py $\mathrm{T}$ antigen nonbound fraction $(X)$. DNA replication was measured by incorporation of radiolabeled nucleotides into acid-precipitable counts. (B) Autoradiogram of DNA products from the reaction mixtures described in the legend to Fig. 5A. All lanes contained human extract and Py ori-DNA templates plus Py T antigen (lanes 1 and 3 to 17) and without Py T antigen (lane 2). Material added: lanes 3 to 7, DNA polymerase $\alpha(28,500 \mathrm{U} / \mathrm{mg}$ ) immunopurified from murine extract; lanes 8 to 12 , DNA polymerase $\alpha(19,000 \mathrm{U} / \mathrm{mg})$ immunopurified from the Py T antigen-bound murine fraction; lanes 13 to $17, \mathrm{DNA}$ polymerase $\alpha(25,000 \mathrm{U} / \mathrm{mg})$ directly immunopurified from the Py $\mathrm{T}$ antigen nonbound fraction.

antigen as well as in their ability to stimulate Py ori-DNA synthesis in extracts of nonpermissive cells.

\section{DISCUSSION}

We have used protein affinity columns to study the interaction between Py T antigen and DNA polymerase $\alpha /$ primase. Our work was based on several observations made by others who examined the interactions between SV40 T antigen and DNA polymerases. Smale and Tjian (43) reversibly coupled SV40 $\mathrm{T}$ antigen to a monoclonal antibody column and then demonstrated that human DNA polymerase $\alpha /$ primase bound efficiently to the $T$ antigen affinity column. Their results strongly suggested that this method could be used for the purification of a protein complex that is an essential step in the initiation of replication. Subsequently, by using an enzymelinked immunosorbent assay (ELISA) $(13,14,18)$, a FarWestern ligand blotting assay (14), or coimmunoprecipitation from recombinant-baculovirus-coinfected insect cells (12), it has been confirmed that there is an interaction between these two proteins. Additionally, there have been reports that SV40 $T$ antigen binds preferentially to human DNA polymerase $\alpha /$ primase. Gough et al. (20) found that immobilized purified SV40 T antigen bound to DNA polymerase $\alpha$ /primase from a human hypotonic extract, but the binding to murine DNA polymerase $\alpha$ /primase from murine T3T3 extracts depleted of p53 was comparatively reduced. Dornreiter et al. (14), using an ELISA showed that SV40 $\mathrm{T}$ antigen binding to human DNA polymerase $\alpha$ was approximately 10 -fold greater than it was to the corresponding bovine enzyme. Specific protein-protein interaction was not limited to the $\mathrm{T}$ antigen-DNA polymerase $\alpha /$ primase interaction: Dornreiter et al. (13), again using the ELISA, also detected specific binding of human DNA polymerase $\alpha$ /primase to human RP-A and reduced binding to Escherichia coli SSB and bacteriophage T4 gene 32 protein. Consistent with the reported physical binding described above, assays have been used to examine the functional interactions between SV40 T antigen, DNA polymerase $\alpha$ /primase, and RPA as well. Collins and Kelly (9) reported that SV40 T antigen stimulates human DNA primase activity and can also relieve the inhibition of this activity by both human RPA and $E$. coli single-stranded-DNA-binding protein (SSB). Melendy and Stillman (29) demonstrated that SV40 T antigen is capable of stimulating priming by human DNA polymerase $\alpha /$ primase in the presence of human or murine RPA but not yeast RPA or $E$. coli SSB. Additionally, it was reported that bovine RPA substitutes for human RPA in SV40 replication in vitro (35). Together, these studies suggest that mammalian forms of RPA are functionally interchangeable for SV40 DNA replication, whereas mammalian DNA polymerase $\alpha$ /primases are not.

We found that a Py $\mathrm{T}$ antigen affinity column loaded with a replication-competent murine hypotonic extract retained a fraction that contained a minor proportion of the total DNA polymerase $\alpha$ activity. The retention was demonstrably species specific, because an insignificant quantity of DNA polymerase $\alpha$ activity was retained when an equivalent Py $T$ antigen column was loaded with human hypotonic extract. This was further confirmed by immobilizing DNA polymerase $\alpha /$ pri- 


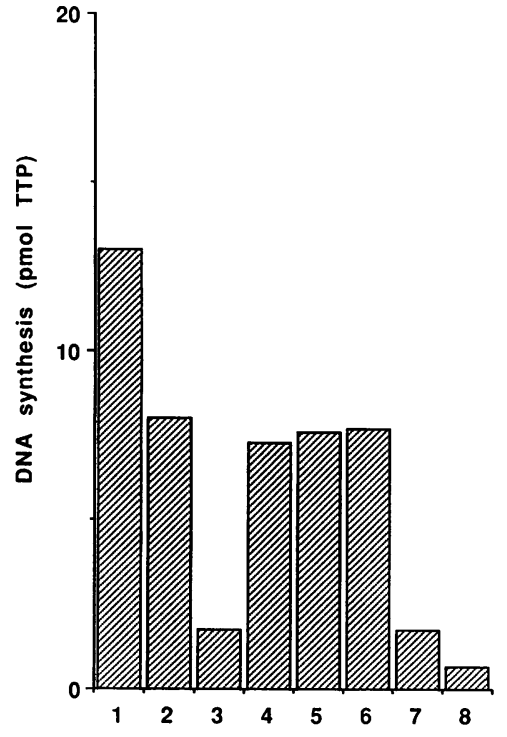

Tube number

FIG. 7. Nonbound DNA polymerase $\alpha$ /primase fraction does not inhibit Py $\mathrm{T}$ bound DNA polymerase $\alpha /$ primase. The following fractions were added to Py ori-DNA replication supported by human extract (described in the legend to Fig. 1B) in the indicated quantities and incubated for $3 \mathrm{~h}$ at $33^{\circ} \mathrm{C}$. All tubes contained human extract and Py ori-DNA templates; tubes 1 to 7 also had Py T antigen. Material added: tube $1,10 \mathrm{U}$ of DNA polymerase $\alpha(28,500 \mathrm{U} / \mathrm{mg})$ immunopurified from murine extract; tube 2, $10 \mathrm{U}$ of DNA polymerase $\alpha$ $(19,000 \mathrm{U} / \mathrm{mg})$ immunopurified from the Py T antigen-bound murine fraction $(15,000 \mathrm{U} / \mathrm{mg})$; tube $3,10 \mathrm{U}$ of DNA polymerase $\alpha(25,000$ $\mathrm{U} / \mathrm{mg}$ ) directly immunopurified from the nonbound fraction; tubes 4 to $6,10 \mathrm{U}$ of DNA polymerase $\alpha$ immunopurified from the Py T antigen-bound murine fraction plus $3 \mathrm{U}$ (tube 4), $5 \mathrm{U}$ (tube 5), or 10 $U$ (tube 6) of DNA polymerase $\alpha$ activity directly immunopurified from the nonbound fraction; tubes 7 and 8 , hypotonic buffer alone.

mase on an anti-DNA polymerase $\alpha$ column and examining its affinity for Py T antigen. A murine DNA polymerase $\alpha$ affinity column displayed greater binding of Py $T$ antigen than did a human DNA polymerase $\alpha$ affinity column. The Py T antigenbound murine fraction contained a DNA polymerase $\alpha /$ primase activity that can stimulate Py ori-DNA replication in a human hypotonic extract and can directly bind Py $\mathrm{T}$ antigen. By contrast, the DNA polymerase $\alpha /$ primase activity in the nonbound murine fraction did not stimulate Py DNA replication and showed a significantly reduced ability to bind Py T antigen. While characterization of the cause of this difference is not yet complete, our data suggest that it is not due to inactive DNA primase or an inhibitor of DNA polymerase $\alpha /$ primase.

Eukaryotic DNA polymerase $\alpha$ holoenzymes typically consist of four polypeptides (55). The murine holoenzyme contains a large $180-\mathrm{kDa}$ catalytic subunit, a $68-\mathrm{kDa}$ polypeptide, and two smaller polypeptides, 54 and $46 \mathrm{kDa}$, that carry out the synthesis of primers. It is of interest to determine which polypeptides are involved in the interaction with $\mathrm{T}$ antigen and which play a role in the species specificity of these interactions. Dornreiter et al. (14), using a Far-Western technique, established that the large catalytic subunit (p180) of human DNA polymerase $\alpha$ binds directly to SV40 T antigen. Later work by this group (13) has also established that SV40 T antigen binds to intact human DNA polymerase $\alpha /$ primase and RPA but not

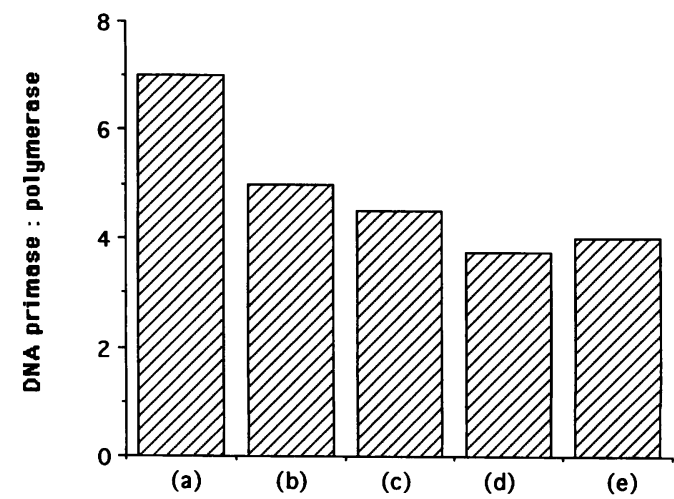

FIG. 8. DNA primase activity does not correlate with stimulatory activity of DNA polymerase fractions. Aliquots of (a) murine extract, (b) DNA polymerase $\alpha$ /primase immunopurified from murine extract, (c) Py T antigen-bound murine fraction, (d) DNA polymerase $\alpha /$ primase immunopurified from the Py $\mathrm{T}$ antigen-bound murine fraction, and (e) DNA polymerase $\alpha$ /primase immunopurified from the Py T antigen-nonbound murine fraction were assayed for DNA polymerase $\alpha$ and DNA primase activities. The results shown are ratios of units of DNA primase to DNA polymerase activity for each fraction.

to any of the separated subunits of RPA or to the isolated DNA primase. Furthermore, it has been established that specific domains of SV40 T antigen interact with DNA polymerase $\alpha$. Regions located in the carboxy-terminal ATPase domain, i.e., within residues 260 to $708(8,18,43)$ and the amino-terminal 83 amino acids (14) of $T$ antigen, are essential for binding to DNA polymerase $\alpha$. Reciprocally, the region of the catalytic subunit of DNA polymerase $\alpha$ that binds to SV40 $T$ antigen has been identified and shown to include residues 195 to 313 (12). All of the above results strongly indicate that the large DNA polymerase $\alpha$ subunit binds directly to $T$ antigen and thus may be responsible for species-specific interactions with the viral protein. However, Eki et al. (15) observed that the isolated murine DNA primase p54 and p46 subunits alone stimulated the replication of Py ori-DNA replication supported by human hypotonic extracts. Their data therefore suggest that the interaction between the human DNA polymerase $\alpha$ p180 subunit and SV40 T antigen does not have a role in permissiveness.

A mechanism that may resolve these results is as follows. The p180 subunit of DNA polymerase $\alpha$ can bind to either human or murine DNA primase as well as to either SV40 or Py $T$ antigen. While this interaction is not itself species specific, the complex so formed interacts species specifically. The model predicts that purified Py T antigen can bind to both the murine and human p180 isolated subunits but not when they are part of their respective holoenzymes. It can also be speculated that the p70 subunit of the DNA polymerase $\alpha$ holoenzyme, upon interaction with the p180 subunit, forms a p180-p70 complex that species specifically interacts with $T$ antigen and DNA primase. This suggestion is supported by recent evidence that human p70 serves the function of tethering the catalytic subunit of DNA polymerase $\alpha$ to SV40 T antigen (9a). Alternatively, it may also be the case that the p180 catalytic subunit is the determinant of species specificity for SV40, while the primase subunit(s) serves that purpose for Py ori-DNA replication. Furthermore, since our experiments demonstrating the species specificity of $\mathrm{T}$ antigen for DNA polymerase were done with crude extracts, it remains possible that additional factors are also required. Clearly, it will be necessary to 


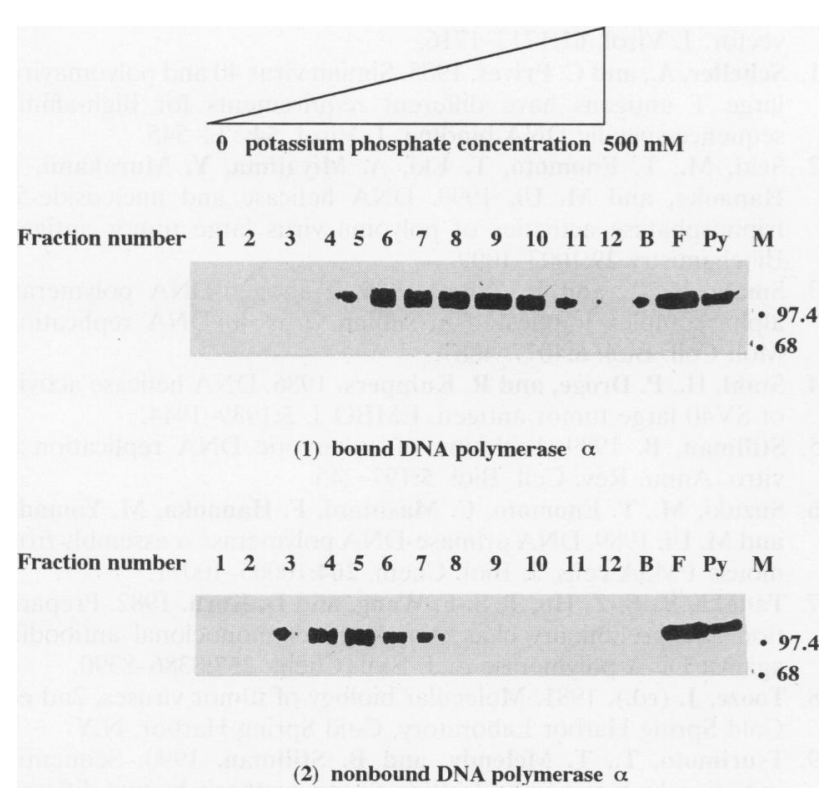

FIG. 9. Interaction of Py $\mathrm{T}$ antigen with immobilized DNA polymerase $\alpha$ /primase. Anti-DNA polymerase $\alpha$ columns (SJK 132-20 coupled to protein G-Sepharose, $1 \mathrm{ml}$ ) were loaded with either (panel 1) the Py T antigen-bound murine fraction $(22 \mu \mathrm{g}, 15,000 \mathrm{U} / \mathrm{mg}, 330$ $\mathrm{U}$ ) or (panel 2) nonbound murine fraction ( $87 \mathrm{mg}, 1.7 \mathrm{U} / \mathrm{mg}, 147 \mathrm{U})$. The columns were then washed and equilibrated with hypotonic buffer before being loaded with a saturating quantity of crude Py $T$ antigen baculovirus extract. Bound proteins were eluted from the column with $35-\mathrm{ml}$ linear potassium phosphate gradients $(0$ to $500 \mathrm{mM})$. Collected fractions (1 through 12) were acid precipitated and resuspended in 0.1 $\mathrm{ml} ; 20-\mu \mathrm{l}$ aliquots were analyzed by SDS-PAGE and Western blotting for Py T antigen. Lane B, material boiled off of $30 \mu \mathrm{l}$ of a $50 \%$ solution of the beads after elution. Lane F, 20- $\mu$ l aliquot of the crude extract that did not bind to the column. Lane Py, purified Py T antigen marker. The positions of size markers are shown (in kilodaltons).

continue to define and extend the factors and conditions necessary for species-specific Py ori-DNA replication.

The data presented in this article suggest that in addition to a species-specific interaction between Py T antigen and DNA polymerase $\alpha /$ primase, there may be subclasses of murine DNA polymerase $\alpha /$ primase that differ in their interactions with Py $\mathrm{T}$ antigen. As yet we do not know the basis for these differences other than that it is unlikely to be related to the relative amount of DNA primase activity associated with each of the two classes. One attractive possibility is that the two populations of DNA polymerase $\alpha$ /primase may differ in posttranslational modification. Nasheuer et al. (34) identified a cell cycle-dependent phosphorylation of the p180 and p70 subunits of DNA polymerase $\alpha$. They found that increased levels of phosphorylation during the $G_{2}-M$ phase reduced the affinity of DNA polymerase $\alpha$ for single-stranded DNA, suggesting that differential phosphorylation of DNA polymerase $\alpha /$ primase is a trigger step in a cell entering the DNAreplicative phase or a consequence of the cell's entering the DNA-replicative phase. We are currently attempting to characterize the differences between the two populations of murine DNA polymerase $\alpha /$ primase that we have identified.

\section{ACKNOWLEDGMENTS}

We thank E. Fanning and members of her laboratory for critical comments on the manuscript. E. Freulich provided superb technical assistance.
This study was supported by NIH grant CA-26905.

\section{REFERENCES}

1. Bambara, R. A., and C. B. Jessee. 1991. Properties of DNA polymerases $\delta$ and $\varepsilon$, and their roles in eukaryotic DNA replication. Biochim. Biophys. Acta 1088:11-24.

2. Basilico, C. 1971. The multiplication of polyoma virus in mouse hamster somatic hybrids, p. 12-27. In L. Silvestri (ed.), The biology of oncogenic viruses. 2nd Lepetit Colloquium. Elsevier, New York.

3. Bolen, J. B., and M. A. Israel. 1985. Middle tumor antigen of polyomavirus transformation-defective mutant NG59 is associated with pp60 $0^{\mathrm{c}-s r c}$. J. Virol. 53:114-119.

4. Borowiec, J. A., F. B. Dean, P. A. Bullock, and J. Hurwitz. 1990. Binding and unwinding-how $\mathrm{T}$ antigen engages the SV40 origin of DNA replication. Cell 60:181-184.

5. Bullock, P. A., Y. S. Seo, and J. Hurwitz. 1989. Initiation of simian virus 40 replication in vitro: pulse-chase experiments identify the first labeled species as topologically unwound. Proc. Natl. Acad. Sci. USA 86:3944-3948.

6. Byrnes, J. J. 1985. Differential inhibitors of DNA polymerases alpha and delta. Biochem. Biophys. Res. Commun. 132:628-634.

7. Challberg, M., and T. J. Kelly. 1989. Animal virus DNA replication. Annu. Rev. Biochem. 58:671-717.

8. Clark, R., D. Lane, and R. Tjian. 1981. Use of monoclonal antibodies as probes of simian virus $40 \mathrm{~T}$ antigen ATPase activity. J. Biol. Chem. 256:11854-11858.

9. Collins, K. L., and T. J. Kelly. 1991. Effects of T antigen and replication protein $A$ on the initiation of DNA synthesis by DNA polymerase $\alpha$ /primase. Mol. Cell. Biol. 11:2108-2115.

9a.Collins, K. L., A. R. Russo, B. Y. Tseng, and T. J. Kelly. 1993. The role of the $70 \mathrm{kDa}$ subunit of human DNA polymerase $\alpha$ in DNA replication. EMBO J. 12:4555-4566.

10. Cowie, A., and R. Kamen. 1986. Guanine nucleotide contacts within viral DNA sequences bound by polyomavirus large $T$ antigen. J. Virol. 57:505-514.

11. Dean, F. B., P. A. Bullock, Y. Murakami, C. R. Wobbe, L. Weissbach, and J. Hurwitz. 1987. Simian virus 40 (SV40) DNA replication: SV40 large $T$ antigen unwinds DNA containing the SV40 origin of replication. Proc. Natl. Acad. Sci. USA 84:16-20.

12. Dornreiter, I., W. C. Copeland, and T. S.-F. Wang. 1993. Initiation of simian virus 40 DNA replication requires the interaction of a specific domain of human DNA polymerase $\alpha$ with large T antigen. Mol. Cell. Biol. 13:809-820.

13. Dornreiter, I., L. F. Erdile, I. U. Gilbert, D. von Winkler, T. J. Kelly, and E. Fanning. 1992. Interaction of DNA polymerase $\alpha$-primase with cellular replication protein A and SV40 T antigen. EMBO J. 11:769-776.

14. Dornreiter, I., A. Hoss, A. K. Arthur, and E. Fanning. 1990. SV40 $T$ antigen binds directly to the large subunit of purified DNA polymerase $\alpha$. EMBO J. 10:3329-3336.

15. Eki, T., T. Enomoto, C. Masutani, A. Miyajima, R. Takada, Y. Murakami, T. Ohno, F. Hanaoka, and M. Ui. 1991. Mouse DNA primase plays the principal role in determination of permissiveness for polyomavirus DNA replication. J. Virol. 65:4874-4881.

16. Erdile, L. F., W. D. Heyer, R. Kolodner, and T. J. Kelly. 1991. Characterisation of a cDNA encoding the 70kd single-stranded DNA-binding subunit of human replication protein $A$ and the role of the protein in DNA replication. J. Biol. Chem. 266:12090-12098.

17. Fanning, E., and R. Knippers. 1992. Structure and function of simian virus 40 large $T$ antigen. Annu. Rev. Biochem. 61:55-85.

18. Gannon, J. V., and D. P. Lane. 1987. p53 and DNA polymerase $\alpha$ compete for binding to SV40 T antigen. Nature (London) 329: 456-458.

19. Gaudray, P., P. Clertant, and F. Cuzin. 1980. ATP phosphorylase (ATPase) activity of a polyoma $T$ antigen. Eur. J. Biochem. 109: 553-560.

20. Gough, G., J. V. Gannon, and D. P. Lane. 1988. Competition between DNA polymerase $\alpha$ and p53 for binding to SV40 T antigen. Cancer Cells 6:153-158.

21. Hay, R. T., and W. C. Russell. 1989. Recognition mechanisms in the synthesis of animal virus DNA. Biochem. J. 258:3-16.

22. Hurwitz, J., F. B. Dean, A. D. Kwong, and S.-H. Lee. 1990. The in vitro replication of DNA containing the SV40 origin. J. Biol. 
Chem. 265:18043-18046.

23. Kenny, M. K., U. Schelegal, H. Furneaux, and J. Hurwitz. 1990. The role of human single-stranded DNA binding protein and its individual subunits in simian virus 40 DNA replication. J. Biol. Chem. 265:7693-7700.

24. Kern, F. G., L. Dailey, and C. Basilico. 1985. Common regulatory elements control gene expression from polyomavirus early and late promoters in cells transformed by chimeric plasmids. Mol Cell. Biol. 5:2070-2079.

25. Li, J. J., and T. J. Kelly. 1984. Simian virus 40 replication in vitro. Proc. Natl. Acad. Sci. USA 81:6973-6977.

26. Li, J. J., and T. J. Kelly. 1985 . Simian virus 40 DNA replication in vitro: specificity of initiation and evidence for bidirectional replication. Mol. Cell. Biol. 5:1238-1246.

27. Lorimer, H. E., E. H. Wang, and C. Prives. 1991. The DNAbinding properties of polyomavirus large $\mathrm{T}$ antigen are altered by ATP and other nucleotides. J. Virol. 65:687-699.

28. Mastrangelo, I. A., P. V. C. Hough, J. S. Wall, M. Dodson, F. B. Dean, and J. Hurwitz. 1989. ATP-dependent assembly of double hexamers of SV40 T antigen at the viral origin of DNA replication. Nature (London) 338:658-662.

29. Melendy, T., and B. Stillman. 1993. An interaction between replication protein $\mathrm{A}$ and SV40 $\mathrm{T}$ antigen appears essential for primosome assembly during SV40 DNA replication. J. Biol. Chem. 268:3389-3395.

30. Morrison, A., H. Araki, A. B. Clark, R. K. Hamatake, and H. Sugino. 1990. A third essential DNA polymerase in S. cerevisiae. Cell 62:1143-1151.

31. Murakami, Y., T. Eki, M. Yamada, C. Prives, and J. Hurwitz. 1986. Species-specific in vitro synthesis of DNA containing the polyoma virus origin of replication. Proc. Natl. Acad. Sci. USA 83:6347-6351.

32. Murakami, Y., C. R. Wobbe, L. Weissbach, F. B. Dean, and J. Hurwitz. 1986. Role of DNA polymerase $\alpha$ and DNA primase in simian virus 40 DNA replication in vitro. Proc. Natl. Acad. Sci. USA 83:2869-2873.

33. Nasheuer, H.-P., and F. Grosse. 1987. Immunoaffinity-purified DNA polymerase $\alpha$ displays novel properties. Biochemistry 26: 8458-8466.

34. Nasheuer, H.-P., A. Moore, A. F. Wahl, and T. S.-F. Wang. 1991 Cell cycle dependent phosphorylation of human DNA polymerase a. J. Biol. Chem. 266:7893-7903.

35. Nasheuer, H.-P., D. von Winkler, C. Schneider, I. Dornreiter, I. Gilbert, and E. Fanning. 1992. Purification and functional characterisation of bovine RP-A in an in vitro SV40 DNA replication system. Chromosoma 102:S52-S59.

36. O'Reilly, D. R., and L. K. Miller. 1988. Expression and complex formation of simian virus 40 large $T$ antigen and mouse p53 in insect cells. J. Virol. 60:3109-3119.

37. Pallas, D. C., C. Schley, M. Mahoney, E. Harlow, B. S. Schaffhausen, and T. M. Roberts. 1986. Polyomavirus small $t$ antigen: overproduction in bacteria, purification, and utilization for monoclonal and polyclonal antibody production. J. Virol. 60:1075-1084.

38. Pomerantz, B. J., and J. A. Hassell. 1984. Polyomavirus and simian virus 40 large $\mathrm{T}$ antigens bind to common DNA sequences. $\mathrm{J}$. Virol. 49:925-937.

39. Prives, C. 1990. The replication functions of SV40 T antigen are regulated by phosphorylation. Cell 61:735-738.

40. Rice, W. C., H. E. Lorimer, C. Prives, and L. K. Miller. 1987. Expression of polyomavirus large $\mathrm{T}$ antigen by using a baculovirus vector. J. Virol. 61:1712-1716.

41. Scheller, A., and C. Prives. 1985. Simian virus 40 and polyomavirus large $\mathrm{T}$ antigens have different requirements for high-affinity sequence-specific DNA binding. J. Virol. 54:532-545.

42. Seki, M., T. Enomoto, T. Eki, A. Miyajima, Y. Murakami, F. Hanaoka, and M. Ui. 1990. DNA helicase and nucleoside-5'triphosphatase activities of polyoma virus large tumor antigen. Biochemistry 29:1003-1009.

43. Smale, S. T., and R. Tjian. 1986. T-antigen-DNA polymerase alpha complex implicated in simian virus 40 DNA replication. Mol. Cell. Biol. 6:4077-4087.

44. Stahl, H., P. Droge, and R. Knippers. 1986. DNA helicase activity of SV40 large tumor antigen. EMBO J. 5:1939-1944.

45. Stillman, B. 1989. Initiation of eukaryotic DNA replication in vitro. Annu. Rev. Cell. Biol. 5:197-245.

46. Suzuki, M., T. Enomoto, C. Masutani, F. Hanaoka, M. Yamada, and M. Ui. 1989. DNA primase-DNA polymerase $\alpha$ assembly from mouse FM3A cells. J. Biol. Chem. 264:10065-10071.

47. Tanaka, S., S.-Z. Hu, T. S.-F. Wang, and D. Korn. 1982. Preparation and preliminary characterization of monoclonal antibodies against DNA polymerase $\alpha$. J. Biol. Chem. 257:8386-8390.

48. Tooze, J. (ed.). 1981. Molecular biology of tumor viruses, 2nd ed. Cold Spring Harbor Laboratory, Cold Spring Harbor, N.Y.

49. Tsurimoto, T., T. Melendy, and B. Stillman. 1990. Sequential initiation by lagging and leading strand synthesis by two different polymerase complexes at the SV40 DNA replication origin. Nature (London) 346:534-539.

50. Tsurimoto, T., and B. Stillman. 1991. Replication factors required for SV40 DNA replication in vitro. I. DNA structure specific recognition of a primer-template junction by eukaryotic DNA polymerase and their accessory proteins. J. Biol. Chem. 264:1950 1960.

51. Tsurimoto, T., and B. Stillman. 1991. Replication factors required for SV40 DNA replication in vitro. II. Switching of DNA polymerase $\alpha$ and $\delta$ during initiation of leading and lagging strand synthesis. J. Biol. Chem. 264:1961-1968.

52. Wang, E. H., P. N. Friedman, and C. Prives. 1989. The murine p53 protein blocks replication of SV40 DNA in vitro by inhibiting the initiation functions of SV40 large T antigen. Cell 57:379-392.

53. Wang, E. H., and C. Prives. 1991. DNA helicase and duplex DNA fragment unwinding activities of polyoma and simian virus 40 large $\mathrm{T}$ antigen display similarities and differences. J. Biol. Chem. 266:12668-12675.

54. Wang, E. H., and C. Prives. 1991. ATP induces the assembly of polyoma large $T$ antigen into hexamers. Virology 184:399-403.

55. Wang, T. S.-F. 1991. Eukaryotic DNA polymerases. Annu. Rev. Biochem. 60:513-552.

56. Weinberg, D. H., K. L. Collins, P. Simancek, A. Russo, M. S. Wold, D. M. Virshup, and T. J. Kelly. 1990. Reconstitution of SV40 DNA replication with purified proteins. Proc. Natl. Acad. Sci. USA 87:8692-8696.

57. Wold, M. S., and T. J. Kelly. 1988. Purification and characterization of replication protein $\mathrm{A}$, a cellular protein required for in vitro replication of simian virus 40 DNA. Proc. Natl. Acad. Sci. USA 85:2523-2527.

58. Wold, M. S., J. J. Li, and T. J. Kelly. 1987. Initiation of simian virus 40 DNA replication in vitro: large-tumor-antigen- and origindependent unwinding of the template. Proc. Natl. Acad. Sci. USA 84:3643-3647. 